\title{
Effects of mercury on enclosed plankton communities in the Rosfjord during POSER
}

\author{
J. Kuiper ${ }^{1}$, U. H. Brockmann ${ }^{2}$, H. van het Groenewoud ${ }^{1}$, G. Hoornsman ${ }^{1}$ and P. Roele ${ }^{1}$ \\ ${ }^{1}$ Laboratory for Applied Marine Research, Division of Technology for Society MT-TNO, P.O.Box 57, 1780 AB Den Helder, \\ The Netherlands \\ ${ }^{2}$ Institut für Organische Chemie und Biochemie, SFB 94, Universität Hamburg, Martin-Luther-King-Platz 6, \\ D-2000 Hamburg 13, Federal Republic of Germany
}

\begin{abstract}
ABSTRACr: During POSER 2 experiments were performed to study the effects of a single addition of mercury (II) chloride on the development of plankton communities enclosed in large plastic bags, containing 1.5 to $30 \mathrm{~m}^{3}$ water and ranging from 3 to $40 \mathrm{~m}$ in depth. The experiments lasted 1 and $3 \mathrm{wk}$, respectively. In one of these experiments the influence of an additional dose of nutrients was studied. During both experiments mercury concentrations in the water decreased after the addition. Part of the mercury was found in the sediment collected on the bottom of the bags during the experiment, but most of the mercury probably volatilized and was lost to the atmosphere. Addition of 1 or $5 \mu \mathrm{g} \mathrm{Hg} \mathrm{l}^{-1}$ in the first experiment resulted in lower numbers of bacteria than in the controls. The first experiment was too short to show effects on phytoplankton and zooplankton. Addition of $5 \mu \mathrm{g} \mathrm{Hg} \mathrm{l}^{-1}$ in the second experiment inhibited bacteria and phytoplankton, and increased the mortality of copepods, which formed the principal part of the zooplankton. Our results are comparable to those obtained during other experiments with natural marine plankton communities also enclosed in large plastic bags in fairly different sea areas. Addition of nutrients stimulated phytoplankton growth, but had no observable effects on bacteria or zooplankton.
\end{abstract}

\section{INTRODUCTION}

Extrapolation of results of laboratory toxicity tests to marine ecosystems is difficult, if not impossible (e. $\mathrm{g}$ Gray, 1974; Menzel and Case, 1977; Perkins, 1979). Experiments with complex systems, which more closely approximate field conditions, are necessary to bridge the apparent gap between laboratory and natural world. Many investigators have used large, flexible plastic enclosures to study the fate and effects of pollutants on aquatic ecosystems (e.g. Schelske and Stoermer, 1972; Menzel and Case, 1977; Zeitzschel, 1978; Davies and Gamble, 1979). By employing this approach to pollution and dumping problems, corresponding laboratory tests can be validated (Hueck et al., 1978); and ecotoxicologists may be able to predict better the influence of pollutants in the field. In this way authorities can be assisted in setting standards to minimize damage to the ecosystem in question (Hueck and Hueck-Van der Plas, 1976; Hueck-Van der Plas and Hueck, 1979).
Since 1974, experiments have been performed to study fate and effects of pollutants on enclosed plankton communities in Dutch coastal waters. We now can experiment with natural plankton systems with several trophic levels and with a large number of species within one experimental unit under semi-natural conditions. No-effect levels found with this method are among the lowest reported in literature (Kuiper, 1980, 1982).

Dutch coastal waters, however, are sediment-laden and polluted. Ten to $15 \%$ of the water used in these bag experiments was freshwater, one third of which came directly from the Rhine after a residence time of approximately 1 mo in the North Sea, the remaining two thirds originated from the Rhine via Lake IJssel (Zimmerman and Rommets, 1974). The biocoenoses in the bags might have reacted differently to environmental stress than those living in the open sea (Fisher et al., 1973; Fisher, 1977), because they had adapted to pollution (Stokes et al., 1973; Jensen et al., 1974; Stockner and Antia, 1976; Moraitou-Apostolopoulou 
and Verriopoulos, 1979) or because of other processes specific to this particular sea area. Results obtained would be of limited significance, if they could be applied only to a very limited area of coastal waters near the Dutch coast. One of the aims of POSER (Plankton Observation with Simultaneous Enclosures in Rosfjorden) was to investigate whether ecotoxicological results obtained in the Rosfjord can be compared with results obtained in Dutch coastal waters. Rosfjord was chosen because of its low freshwater input and because its waters were relatively unpolluted (Brockmann et al., 1983).

During POSER, 2 experiments were performed with mercury as a model pollutant. Mercury was chosen since the results of many experiments with mercury and enclosed marine plankton communities were available for comparison (Grice and Menzel, 1978; Davies and Gamble, 1979; Kuiper, 1977, 1980, 1981; Topping et al., 1982).

\section{MATERIALS AND METHODS Set-up and course of the experiments}

On March 6, 1979 the first experiment (POSER 1) was started. Six small bags ( $3 \mathrm{~m}$ deep, $1.5 \mathrm{~m}^{3}$ volume) were filled simultaneously using a Vanton Flex-i-liner pump (Kuiper, 1981). The inflow hose of the pump was moved from a depth of $20 \mathrm{~m}$ to $0.5 \mathrm{~m}$ during pumping. Four large bags ( $40 \mathrm{~m}$ deep, $30 \mathrm{~m}^{3}$ volume) were filled employing the method of Brockmann et al. (1983).

On March 8, single doses of mercury (II) chloride were added to the bags. Two small bags received a dose of $1 \mu \mathrm{g} \mathrm{Hg} \mathrm{l}^{-1} ; 2$ small and 2 large bags received 5 $\mu \mathrm{g} \mathrm{Hg} \mathrm{l} \mathrm{l}^{-1}$; the remaining bags served as controls (Table 1). To add the mercury, a stock solution of mercury (II) chloride was rapidly mixed with $100 \mathrm{l}$ of

Table 1. Set-up of mercury experiments during POSER

\begin{tabular}{|c|c|c|c|c|c|}
\hline \multirow{2}{*}{\multicolumn{2}{|c|}{$\begin{array}{l}\text { Experiment } \\
\text { number and } \\
\text { starting date }\end{array}$}} & \multicolumn{2}{|c|}{$\begin{array}{c}\text { Number } \\
\text { of bags }\end{array}$} & \multirow{2}{*}{$\begin{array}{l}\text { Initial mer- } \\
\text { cury concen- } \\
\text { tration } \mu \mathrm{g} \\
\mathrm{Hg} \mathrm{l}^{-1}\end{array}$} & \multirow[t]{2}{*}{$\begin{array}{c}\text { Nutrients } \\
\text { added }\end{array}$} \\
\hline & & small & large & & \\
\hline \multirow[t]{3}{*}{1} & $6-3-1979$ & 2 & 2 & - & no \\
\hline & & 2 & - & 1 & no \\
\hline & & 2 & 2 & 5 & no \\
\hline \multirow[t]{4}{*}{2} & $16-3-1979$ & 2 & 1 & - & no \\
\hline & & 1 & 1 & 5 & no \\
\hline & & 2 & - & - & yes \\
\hline & & 2 & - & 5 & yes \\
\hline
\end{tabular}

sea water taken from the bag. This mixture was immediately pumped back via a sprinkler, lowered in the bag during pumping to ensure thorough mixing with bag contents.

The development of phytoplankton, zooplankton and bacteria, and a set of physico-chemical parameters influencing the development of the biota (nutrients, $\mathrm{pH}$, temperature), were monitored both in bags and fjord.

All samples, except zooplankton, were taken daily, as a rule at 9 a. m., with a non-metallic sampler (Meyer bottle principle). Small bags were sampled at 0.5 and $2.0 \mathrm{~m}$ depths, large bags and fjord at 1, 3, 10, 20 and $35 \mathrm{~m}$. Zooplankton samples were taken twice a week. In the small bags almost the whole water column $(0$ to $2.5 \mathrm{~m}$ ) was sampled by means of a pipe $(3 \mathrm{~m}$ long, $4.5 \mathrm{~cm}$ diameter) tipped with a ball valve. Each sample (20 l) consisted of 5 random lowerings of the pipe. The contents of the pipe were filtered through a $55 \mu \mathrm{m}$ net, and the material retained was immediately fixed and preserved in a $4 \%$ formaldehyde solution in filtered sea water. Zooplankton samples in the large bags were taken with a $55 \mu \mathrm{m}$ net with a conical opening $(80 \mathrm{~mm}$ diameter). Each sample (176 l assuming a $100 \%$ efficiency) consisted of a vertical haul from $35 \mathrm{~m}$ depth to the surface.

During the first week of the experiment weather conditions were very bad and on March 12 there were strong currents in Børøy Bight. These currents caused a total exchange of water masses in the Børøy Bight (Brockmann et al., 1981). Consequently, a direct comparison of the development of the plankton in the bags with that in the surrounding water, was difficult and the first experiment was stopped.

A second experiment (POSER 2) started on March 16 (Day 0) by filling 7 small and 2 large bags $(20 \mathrm{~m}$ long, $15 \mathrm{~m}^{3}$ volume). It appeared that, within the new water body now present in the Rosfjord, the phytoplankton spring bloom had already occurred as the nutrient concentrations in the water were very low. Since low mineralization rates would occur due to the low water temperatures $\left(-1\right.$ to $\left.+1{ }^{\circ} \mathrm{C}\right)$, we did not expect intensive phytoplankton growth in the bags. Therefore, 4 of the 7 small bags were spiked with nutrients.

The amounts of nutrients added are considered to be comparable to those present before the spring bloom (Lännergren and Skjoldal, 1975). On Day 2 we added

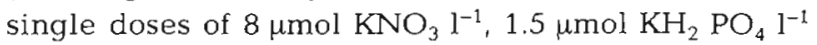
and $5 \mu \mathrm{mol} \mathrm{Na}_{2} \mathrm{SiF}_{6} \mathrm{l}^{-1}$ to some bags (Table 1 ). In addition to nutrients, single doses of mercury (II) chloride were added to some of the bags on the same day. The same parameters were measured as in POSER 1. At the end of the experiment (Day 20) the sediment settled in the small bags was collected for total mercury analysis. 


\section{ANALYTICAL METHODS}

Chlorophyll concentration was measured according to Strickland and Parsons (1968). Prior to filtering 1 l samples through Whatman GF/C filters, $1 \mathrm{ml}$ of a $1 \%$ magnesium carbonate suspension was poured on the filter. The filters were then transferred into $10 \mathrm{ml}$ of $90 \%$ acetone and the cells were extracted after destruction in a Braun MSK cell homogenizer. After centrifugation pigment concentrations were measured with a Vitatron MPS photometer system. Concentrations of chlorophyll and phaeopigments were calculated according to equations given by Lorenzen (1967).

Phytoplankton samples from different depths of each bag were preserved with Lugol's iodine for microscopial inspection with a Zeiss invertoscope. Selected samples were inspected and the main species were identified by means of the nomenclature given by Hendey (1964) and Drebes (1974).

Concentration and size distribution of suspended particulate matter in unpreserved samples were measured with a Coulter Counter model TAII with a population accessory; we used a tube of $100 \mu \mathrm{m}$, or of $280 \mu \mathrm{m}$, or both (Sheldon and Parsons, 1967).

Primary production was measured only in the small bags, employing Steemann Nielsen's (1952) ${ }^{14} \mathrm{C}$ method; $2 \mathrm{ml}$ of a $\mathrm{Na}^{14} \mathrm{CO}_{3}$ solution was added to $100 \mathrm{ml}$ samples in $125 \mathrm{ml}$ light and dark bottles. Ampoules containing an activity of $2.70 \mu \mathrm{Ci} \mathrm{ml}^{-1}$ were supplied by the International Agency of ${ }^{14} \mathrm{C}$ determination (Hørsholm, Denmark). The bottles were incubated in situ, 2 light bottles at a depth of $0.5 \mathrm{~m}, 1$ light and 1 dark bottle at $2.0 \mathrm{~m}$. After $4 \mathrm{~h}$ of incubation (10 a. m. to 2 p.m.) the bottles were transported to the laboratory in a dark box; their contents were then filtered through $0.45 \mu \mathrm{m}$ membrane filters. Filters were counted with a Packard Tricarb liquid scintillation counter. The inorganic carbon content of the water was determined by titration according to Strickland and Parsons (1968).

Employing a Technicon auto-analyzer, concentrations of orthophosphate, nitrate, nitrite and of reactive silicate were measured according to Strickland and Parsons (1968) and Technicon procedures. Zooplankton was counted, identified and measured according to Fransz (1975). The development of bacteria in the water was monitored by the epifluorescence method of Daley and Hobbie (1975). Mercury concentration in the water was measured by atomic absorption spectrometry with an IRDAB HGM 2300 spectrometer according to Spijk (1975). Mercury concentrations in the sediment were measured according to Tjioe et al. (1973).

Mean concentrations in the upper 20 or $40 \mathrm{~m}$ of the water column were calculated following a trapezial integration scheme. Most computations and statistical analyses were performed on the CDC 6400 computer of IWIS-TNO, The Hague. For all cases where no confidence level is given $p \leqslant 0.05$ was tested.

\section{RESULTS}

\section{Technical difficulties}

Strong winds and very low temperatures, with floating freshwater icefields, highly affected the materials. The 2 layers of the bag foils had loosened from each other after 1 or 2 wk, which reduced the mechanical strength of the laminate. Consequently, 2 large bags in POSER 2 showed leakages (the control after Day 10, the other after Day 11) and 1 small bag (mercury treated Bag 6, after Day 10).

During the experiments in the fjord (Brockmann et al., 1981), extensive water exchanges occurred which made a comparison between the development of the plankton inside and outside the bags only useful during the first phase of the experiments. The water exchanges in the Rosfjord led to strong variations in the salinity ( 30 to $34 \% \mathrm{~S}$ ). These salinity changes caused difficulties for the large bags. Whenever the salinity in the fjord was much higher than that in the bags, part of the bags tended to float on the fjord. On one occasion the bottoms of the $20 \mathrm{~m}$ bags were only a few meters under the water surface. By increasing the weight under the bags, we caused the bottom of the bags to sink again, but in this case the heavier water outside pressed the bags together at depths varying from 2 to $10 \mathrm{~m}$. For this reason, sampling of the large bags after Day 12 during POSER 2 was impossible (Case, 1978). The sampling of the small bags was not disturbed by the salinity variations.

\section{Mercury concentrations in water and sediment}

Average mercury concentrations in the water during both experiments are shown in Fig. 1. No large differences were found between different depths, indicating that the mercury was well mixed after the addition. Only in the large bag during POSER 2 was the mercury distribution with depth not homogeneous. On Day 3 only $1.6 \mu \mathrm{g} \mathrm{Hg} \mathrm{l}^{-1}$ was found at a depth of $20 \mathrm{~m}$; in the upper layers $\left(0\right.$ to $10 \mathrm{~m}$ ) an average of $5.9 \mu \mathrm{g} \mathrm{Hg} \mathrm{l}^{-1}$ was measured.

Mercury concentrations in the water decreased in all bags. Owing to bad weather conditions during POSER 1 , sampling was not possible on all days, but in the small bags concentrations seemed to decrease by more than $10 \% \mathrm{~d}^{-1}$. During the second experiment, concen- 


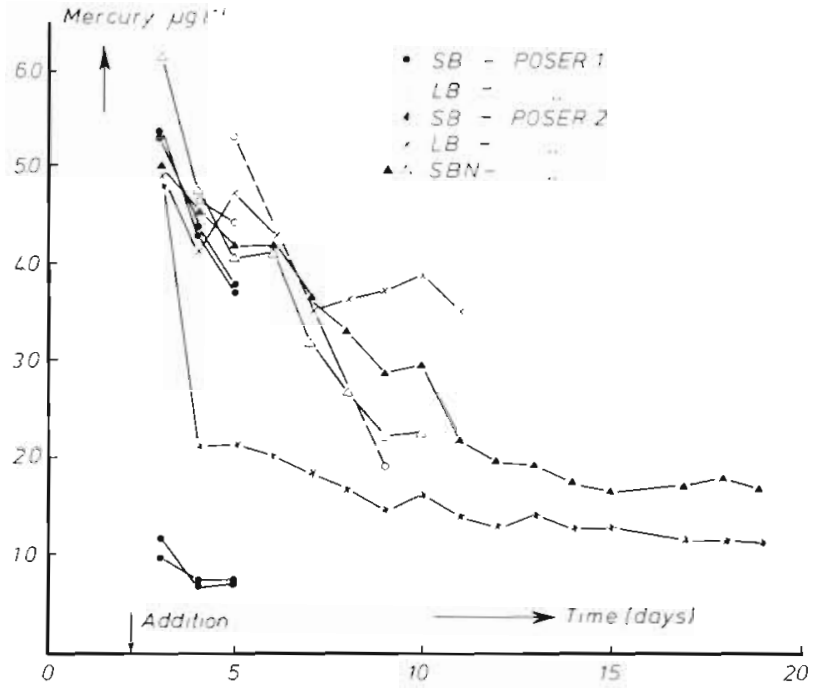

Fig. 1. Mercury concentrations in the bags during POSER 1 (initial concentrations 1 and $5 \mu \mathrm{g} \mathrm{l}^{-1}$ ) and POSER 2 (initial concentration $5 \mu \mathrm{g} \mathrm{Hg} \mathrm{l}^{-1}$ ). For small bags average values at 0.5 and $2.0 \mathrm{~m}$ depth are presented; for large bags, the average of all samples. SB small bag, LB large bag, SBN small bag with nutrients added

trations in the large bag decreased by $4 \% \mathrm{~d}^{-1}$. In the small bag, to which no nutrients had been added, concentrations decreased by $5 \% \mathrm{~d}^{-1}$ after Day 4 . From Day 3 to Day 4 a very rapid decrease occurred.

In the small bags, to which nutrients had been added, the average decrease in mercury concentrations during the first weeks of the experiments was $11 \% \mathrm{~d}^{-1}$. At the end of POSER 2, sediment was collected in the small bags. Collection of sediment in the large bags failed. Table 2 lists the amount of sediment collected and the mercury concentrations found in

Table 2. Mercury concentrations on a wet-weight basis in the sediment of small bags, collected at the end of POSER 2

\begin{tabular}{|c|c|c|c|c|}
\hline Bag & $\begin{array}{c}\text { Mercury } \\
\text { concen- } \\
\text { tration } \\
\left(\mu \mathrm{kg}^{-1}\right)\end{array}$ & $\begin{array}{l}\text { Amount } \\
\text { of sedi- } \\
\text { ment }(g)\end{array}$ & $\begin{array}{c}\text { A } \\
\text { Amount } \\
\text { of mer- } \\
\text { cury } \\
\text { bag }^{-1}(\mu \mathrm{g})\end{array}$ & $\begin{array}{l}\text { A as } \% \text { of } \\
\text { the mer- } \\
\text { cury } \\
\text { added }\end{array}$ \\
\hline 1. control & 319 & 4.6 & 1.5 & - \\
\hline 2. control & 274 & 5.5 & 1.5 & - \\
\hline 3. $5 \mu \mathrm{g} \mathrm{Hg} \mathrm{l}^{-1}$ & 1.280 & 5.5 & 7.1 & 0.1 \\
\hline $\begin{array}{l}\text { 4. Control + } \\
\text { nutrients }\end{array}$ & 160 & 15.4 & 2.5 & - \\
\hline $\begin{array}{l}\text { 5. control }+ \\
\text { nutrients }\end{array}$ & 7 & 28.7 & 0.2 & - \\
\hline $\begin{array}{l}\text { 6. } \mathrm{Hg}+ \\
\text { nutrients }\end{array}$ & 16.100 & 7.6 & 122.7 & 2.2 \\
\hline $\begin{array}{l}\text { 7. } \mathrm{Hg}+ \\
\text { nutrients }\end{array}$ & 18.600 & 16.5 & 307.5 & 5.6 \\
\hline
\end{tabular}

these sediments. Mercury accumulated in the sediment, but only a maximum of $5 \%$ of the added mercury could be recovered.

\section{Phytoplankton}

At the start of POSER 1 the phytoplankton community consisted of diatoms (main species Skeletonema costatum, Thalassiosira nordenskiöldii and Chaetoceros spp.). Fig. 2 shows the chlorophyll concentra-

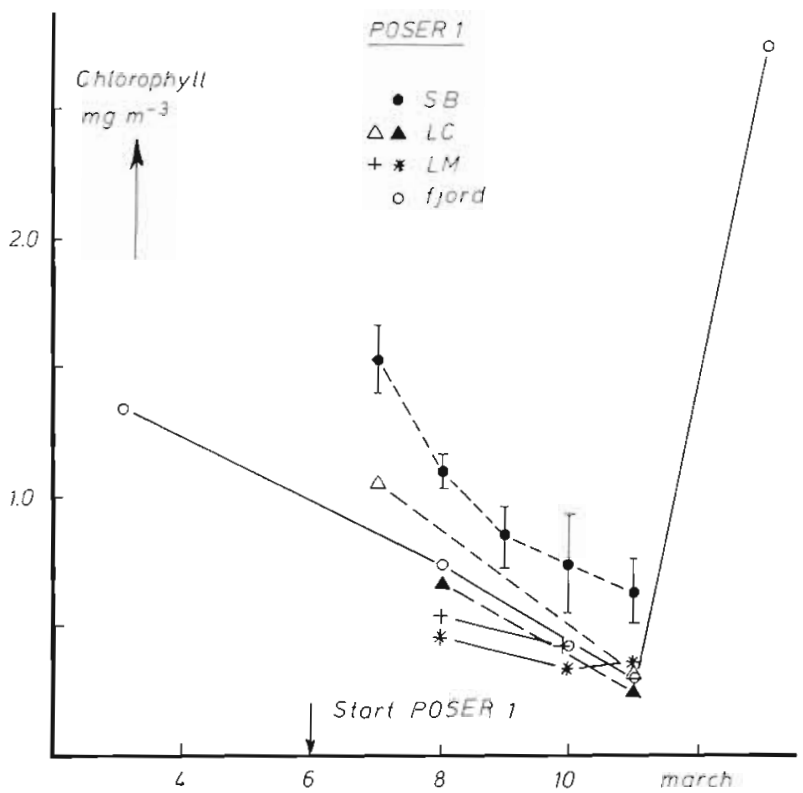

Fig. 2. Chlorophyll concentrations in bags and fjord during POSER 1. Vertical bars: \pm standard deviation. SB small bag,

LC large control bag, LM large mercury-polluted bag

tions in the bags and those in the fjord during the first experiment. In all bags chlorophyll concentrations decreased as they did in the fjord. Since addition of mercury did not influence the development in the small bags, the average concentration for all bags is presented. Constant $\mathrm{pH}$ and constant silicate concentrations as well as the increasing importance of carotenoid pigments relative to chlorophyll indicate that the phytoplankton was not active during this period.

At the start of the second experiment (POSER 2) the water had a relatively low salinity ( 29 to $30 \%$ S) and a low temperature $\left(0\right.$ to $2{ }^{\circ} \mathrm{C}$ ) (Brockmann et al., 1981). After filling, the vertical distribution of the phytoplankton was homogeneous. Thalassiosira nordenskiöldii was the main species, other diatoms found included Thalassionema nitzschioides, Chaetoceros debilis, Chaetoceros borealis, Nitzschia seriata, Coscinodiscus sp. Apart from diatoms a few large flagellates were present (Peridinium sp., Euglena sp.). 


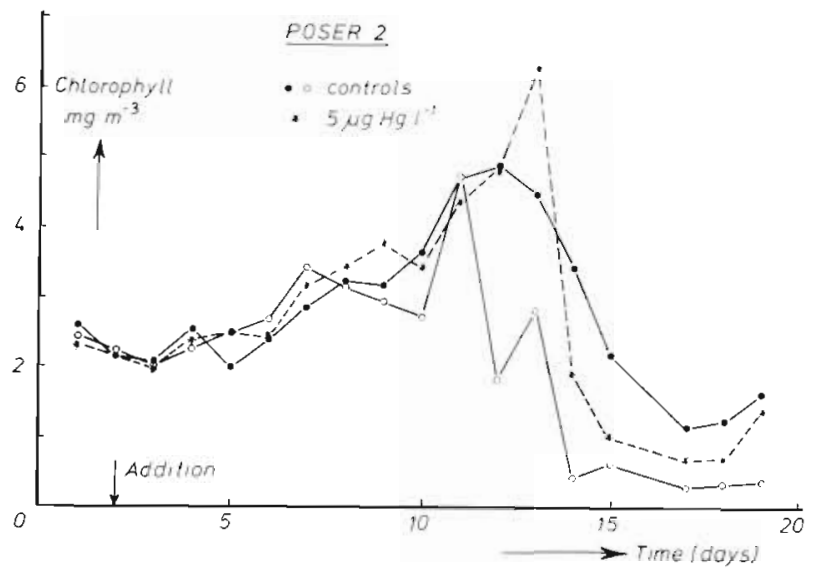

Fig. 3. Chlorophyll concentrations during POSER 2 in small bags not spiked with nutrients

Fig. 3 reveals very similar chlorophyll concentrations in the small bags (not spiked with nutrients, but 1 polluted with $5 \mu \mathrm{g} \mathrm{Hg}^{-1}$ ). Concentrations of suspended particulate matter, measured with the Coulter Counter (size range 4 to $128 \mu \mathrm{m}$ diameter), showed a similar pattern. After Day 6, chlorophyll concentrations increased owing to growth of diatoms, mainly Thalassiosira nordenskiöldii, and, to a lesser extent, Chaetoceros debilis and Chaetoceros borealis. In the large bags the development of average chlorophyll concentrations was very similar to that in these small bags (Kuiper et al., 1983).

Fig. 4 shows the average chlorophyll concentrations in the bags that were spiked with nutrients. Addition of nutrients generated a bloom of diatoms. In these bags, Thalassiosira nordenskiöldii again was the main species; growth of Chaetoceros debilis and

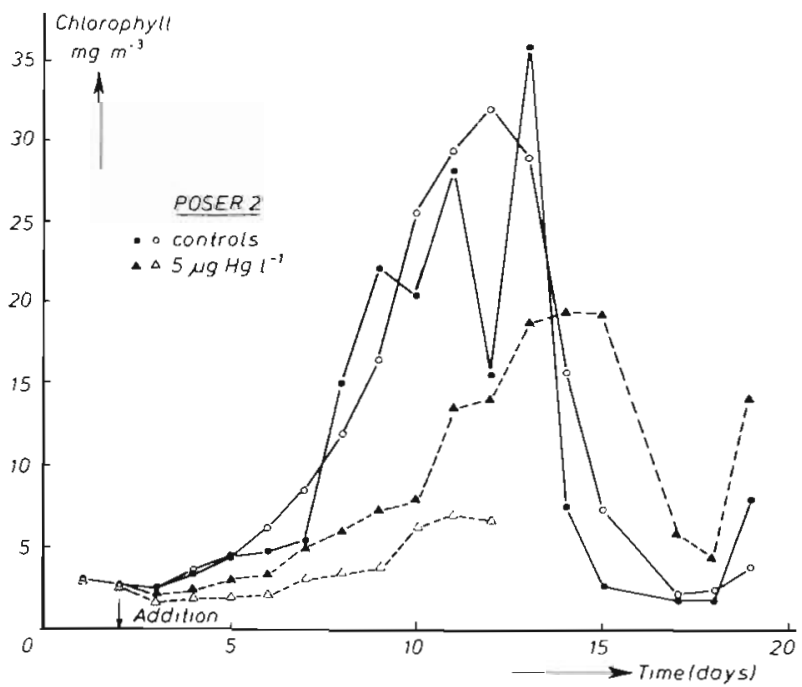

Fig. 4. Chlorophyll concentrations during POSER 2 in the small, nutrient-spiked bags

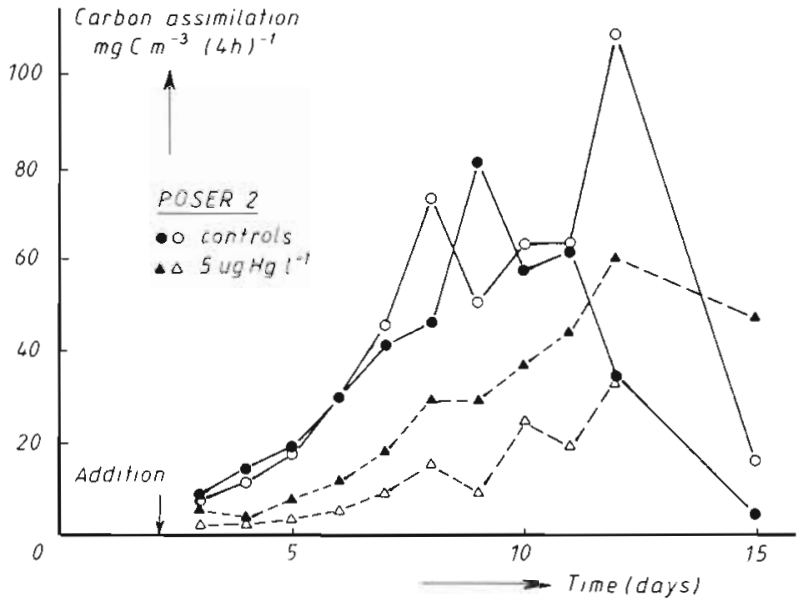

Fig. 5. Carbon assimilation in small bags with nutrient addition (average values at 0.5 and $2.0 \mathrm{~m}$ depth)

Chaetoceros borealis was also found. Maxima in controls are approximately 7 times the maxima in bags without nutrient addition.

Addition of mercury inhibited, for nutrient-enriched bags, the growth of the phytoplankton, which resulted in a delay of maximum of $4 \mathrm{~d}$ as compared with the controls. The same species as in the controls generated this bloom. Concentrations of particulate matter in the

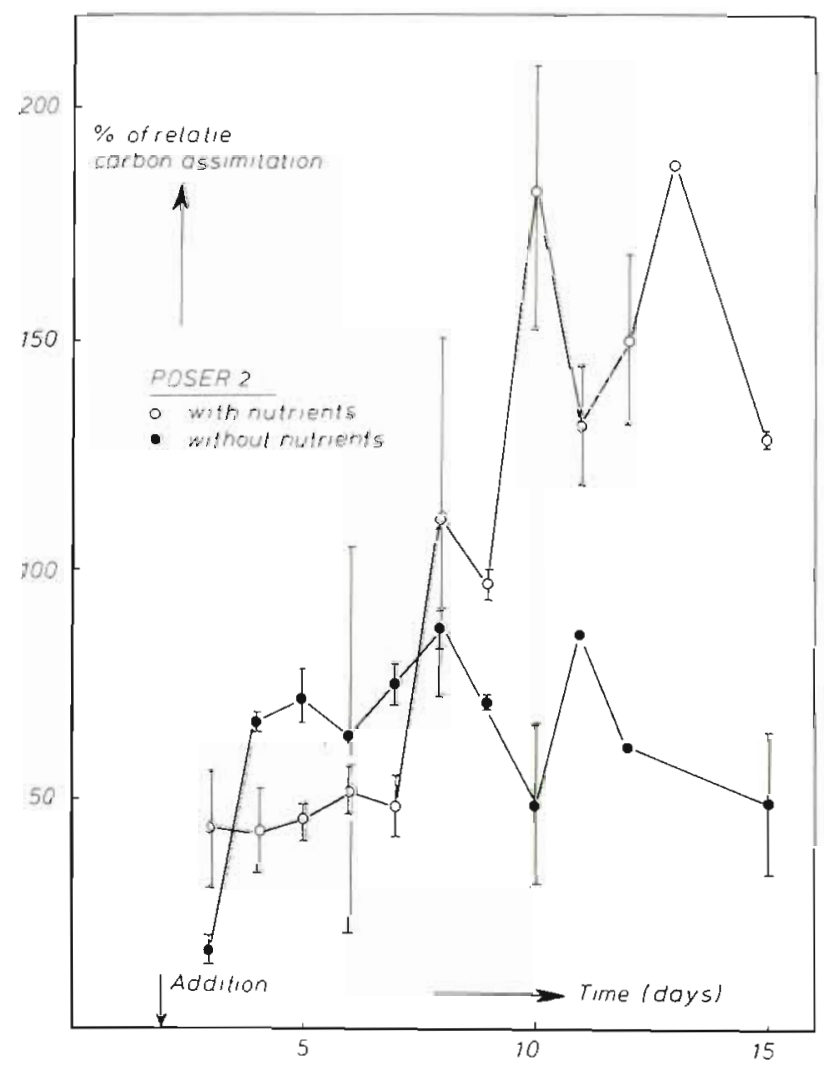

Fig. 6. Relative carbon assimilation (averages at 0.5 and $2.0 \mathrm{~m}$ depth) in mercury-treated bags, expressed a percentage of that in the controls. Vertical bars: $\pm 1 \mathrm{~s}$. d. 

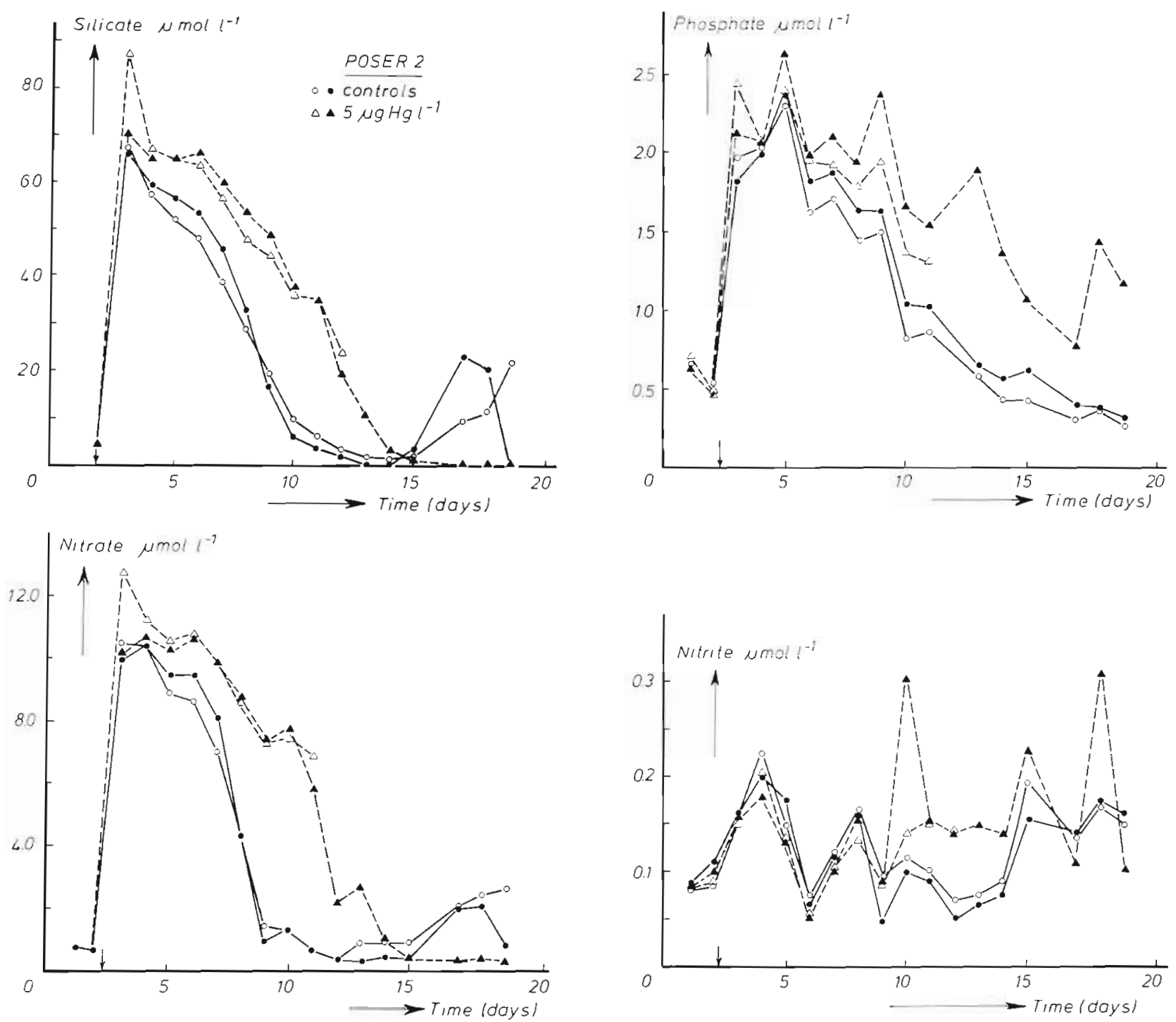

Fig. 7. Concentrations of silicate, nitrate, phosphate and nitrite in small bags with added nutrients

nutrient-enriched bags showed the same pattern with time as chlorophyll.

Fig. 5 shows carbon assimilation in nutrient-spiked enclosures. Again inhibition of phytoplankton after addition of mercury is very clear. Because carbon assimilation rate was partly determined by the biomass of phytoplankton, carbon assimilation per mg chlorophyll was computed. Fig. 6 illustrates this carbon assimilation in mercury-treated bags relative to that in the controls. Since primary productivity at $0.5 \mathrm{~m}$ did not differ from that at $2.0 \mathrm{~m}$, the average relative carbon assimilation was plotted. In the bag that was not spiked with nutrients the relative carbon assimilation was inhibited during the whole experiment. In bags to which nutrients had been added, the relative carbon assimilation was lower than in the controls up to Day 8. From Day 10 to Day 15 relative carbon assimilation was higher in mercury-treated bags than in controls. Nutrient depletion in controls probably caused this difference.

Fig. 7 shows the concentrations of silicate, phosphate, nitrate and nitrite during the second experiment in nutrient-enriched bags. Directly after addition of nutrients phosphate, silicate and nitrate were consumed in the controls by the diatom bloom until one of these nutrients, probably silicate or nitrate or both, reached growth-rate limiting concentrations. Addition of mercury delayed the consumption of nutrients, as could be expected from the development of phytoplankton biomass and productivity. 


\section{Zooplankton}

During the first experiment the zooplankton consisted mainly of calanoid copepods. Nauplii of Calanus finmarchicus were the most important in numbers (see Brockmann et al., 1981 for details). Numbers were very low $\left(1\right.$ to $\left.21^{-1}\right)$. Therefore the samples from the small bags $(20 \mathrm{l})$ were not representative for detection of significant differences between the bags. In the large bags larger samples were taken (176 1), and the numbers of copepods appeared to be lower in the mercurytreated bags than in the controls. However, the first experiment was too short to allow conclusions.

At the start of POSER 2 the species composition of the zooplankton community resembled that during the preceding period. Nauplii of Calanus finmarchicus were most important in numbers. In addition: Acartia clausi, Centropages hamatus, Pseudocalanus elongatus, Oithona similis and an unidentified harpacticoid were found.

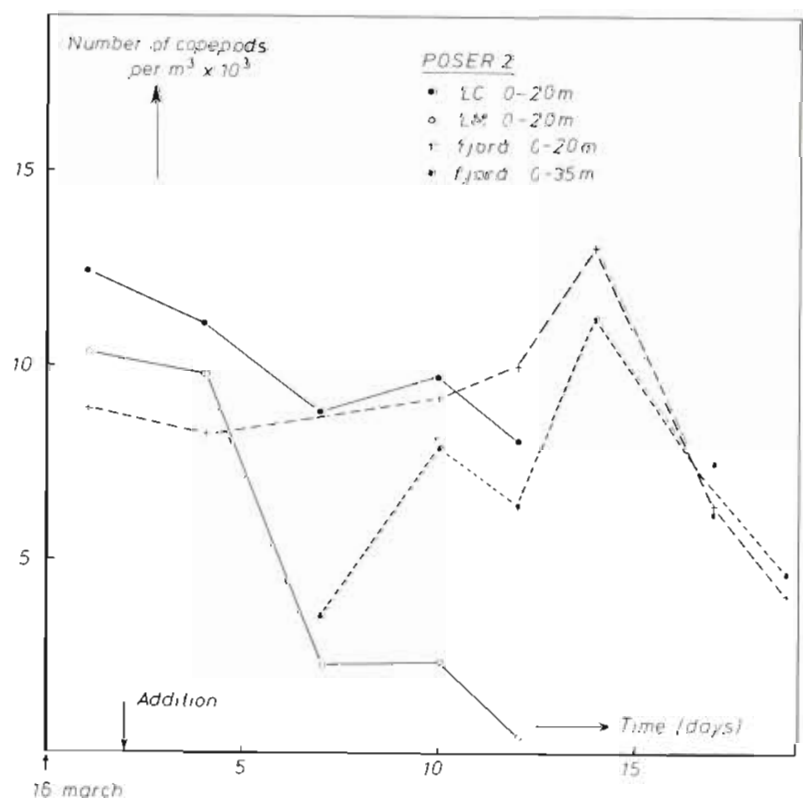

Fig. 8. Total number of copepods in large bags and fjord during POSER 2. LC control bag, LM mercury-polluted bag

Fig. 8 shows the total number of copepods (all species) in the fjord and in the large bags. The changes in the fjord are related to water exchanges; at the start of the experiment, numbers of copepods in the bags were similar to those in the fjord. In both large bags the numbers of copepods declined, but there was a great difference between the bags. On Day 10,65\% of the number found on Day 1 was counted in the control, but in the mercury-polluted enclosure hardly $5 \%$ was found. The decline of the copepods in the control was mainly caused by declining numbers of Calanus fin-

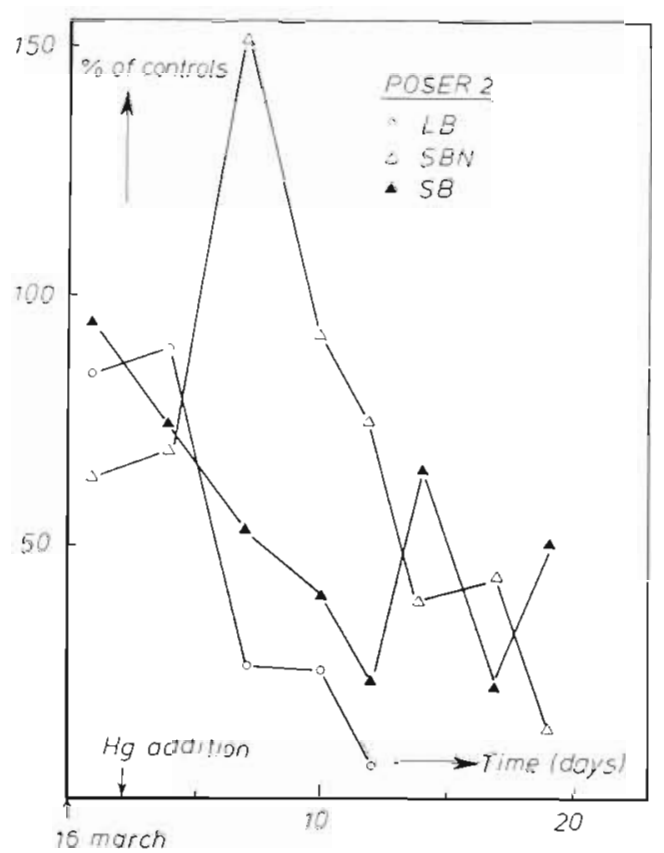

Fig. 9. Numbers of copepods (all species) in mercury-treated bags expressed as percentage of those in the controls. LB large bag, SB small bag, SBN small bag with nutrients added

marchicus. The other species seemed to thrive well. In the mercury-polluted system all species seemed to be influenced, although numbers of Pseudocalanus elongatus and the harpacticoid copepod were too low to allow conclusions. During the experimental period no growth of nauplii towards larger nauplii or copepodites was observed. In all small bags, numbers of all species of copepods decreased sharply (Kuiper et al., 1983), but in mercury-treated bags this decrease was faster than in the controls. Fig. 9 shows the number of copepods (all species) in mercury-treated bags expressed as percentage of copepods in the controls. The variation of this parameter in the small bags is larger than in the large bags due to the lower numbers of organisms in the samples from small bags, and the resulting larger error in the estimation of population density. It is clear, however, that addition of $5 \mu \mathrm{g} \mathrm{Hg} \mathrm{l}^{-1}$ enhanced the mortality of the copepods.

\section{Bacteria}

Fig. 10 shows the number of bacteria in the small bags during POSER 1 . In the controls, numbers increased from 2 to $5.10^{5}$ bacteria $\mathrm{ml}^{-1}$. Addition of 1 and $5 \mu \mathrm{g} \mathrm{l}^{-1}$ inhibited this increase, but at the end of the experiment bacterial numbers also increased in the polluted bags. In the large bags too few samples were taken during POSER 1 to allow any conclusions on the influence of the added mercury. 


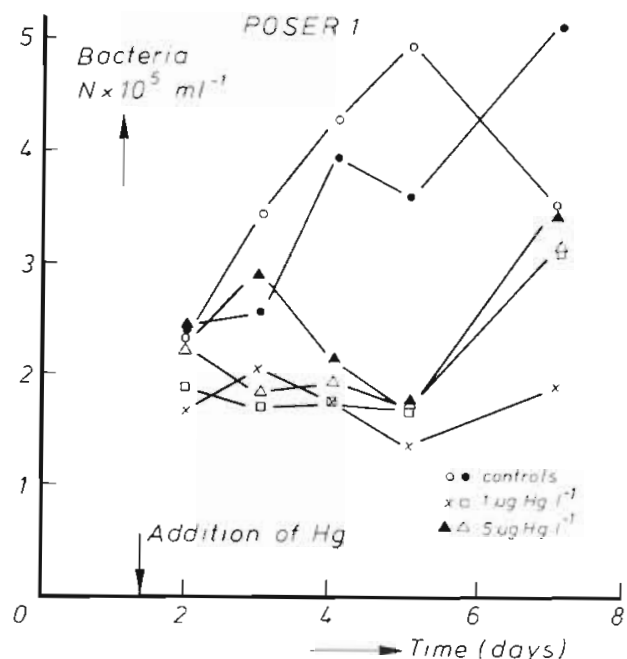

Fig. 10. Development of bacteria in small bags during POSER 1

Fig. 11 shows the number of bacteria in the small bags during POSER 2. In the controls, to which no nutrients had been added, numbers increased slowly during the experiment from 5 to about $14.10^{5}$ bacteria $\mathrm{ml}^{-1}$. Addition of mercury inhibited this increase till Day 8. After Day 12 numbers of bacteria were comparable to those in the controls. In the nutrient-spiked controls, bacteria at first showed a small increase until Day 6, then a decrease and, after Day 10 , an increase to a maximum on Days 14 and 15 .

In the nutrient-spiked bags treated with mercury, numbers of bacteria were lower than in the controls during the first days following the addition of mercury, but after Day 8 numbers increased to a maximum comparable to that in the controls. In the large bags no effects of mercury on the bacteria could be detected during POSER 2.

\section{DISCUSSION AND CONCLUSIONS}

The development of plankton in large versus small enclosures received attention by Kuiper et al. (1983). The general plankton development in the Rosfjord and in the controls is discussed in detail by Brockmann et al. (1981, 1982). Here, the results will be mainly discussed in relation to mercury and to earlier experiments with enclosed marine plankton communities treated with mercury (Grice and Menzel, 1978; Davies and Gamble, 1979; Kuiper, 1977, 1980, 1981; Topping et al., 1982).

\section{Fate of the mercury added}

In earlier experiments, mercury concentrations decreased by 3 to $30 \% \mathrm{~d}^{-1}$ (Kuiper, 1977, 1980, 1981).
Davies and Gamble (1979) found a decrease of $6 \% \mathrm{~d}^{-1}$; Takahashi et al. (1977), of $3 \% \mathrm{~d}^{-1}$. The rate at which mercury disappeared from the water did not seem to be related to bag size, but to the amount of particles available for adsorption and subsequent settling (cf. Topping et al., 1982). Where more nutrients were available for particle production, mercury concentrations decreased faster. High phytoplankton activity also results in a higher production of residuals of phytoplankton cells and extracellular, soluble organic matter, which could form organic complexes with mercury. These complexes may adsorb differently to the walls of the bags and react differently with organisms.
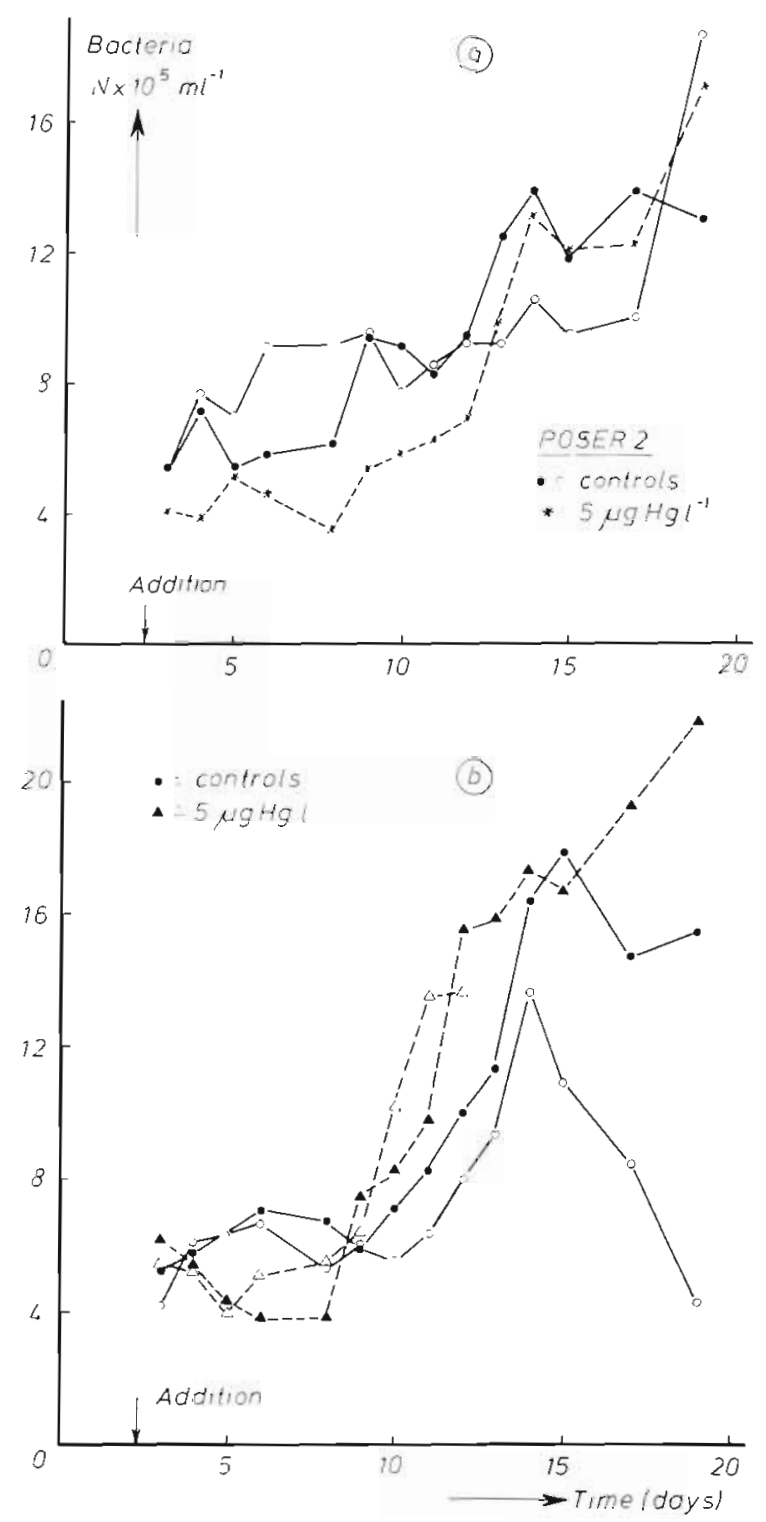

Fig. 11. Numbers of bacteria in small bags without added nutrients (a), and with added nutrients (b). Averages of samples taken at 0.5 and $2.0 \mathrm{~m}$ depth 
At the end of POSER 2, a maximum of only $5.6 \%$ of the mercury added could be recovered from the sediment. Such a low value must be attributed in part to incomplete sediment sampling (part of the sediment was resuspended during sampling), but the sampling error should not have exceeded $100 \%$. In experiments in Den Helder, approximately $25 \%$ was recovered at the end of experiments, a maximum of $10 \%$ was adsorbed to the walls and the remainder was volatilized and disappeared into the atmosphere. Davies and Gamble (1979) recovered 25 to $30 \%$, Topping et al. (1982) found 6 to $25 \%$ in the sediment, and Takahashi et al. (1977) recovered nearly all added mercury in the sediment.

Davies and Gamble (1979) suggest that the larger wall surface to volume ratio in their bags, as compared with Takahashi's, caused relatively higher adsorption to the walls, but Topping et al. (1982) did not measure more than $20 \%$ of the added mercury on the walls, which consisted of PVC foil. Experiments with enclosures containing $68 \mathrm{~m}^{3}$ in Saanich Inlet showed that, per day, $1 \%$ of the added mercury was lost to the atmosphere (Azam, pers. comm.).

The cause for the higher rate of mercury loss from small bags is probably related to reduced mixing and to the relatively smaller surface area available for gas exchange with the atmosphere in very large bags in comparison with the small bags. The amount of mercury that disappears from the sea into the atmosphere under natural conditions is not known; it depends on environmental conditions, time and place. Our results support hypotheses about atmospheric mercury transport put forward by Wollast et al. (1975). Brosset and Svedung (1977) also found strong indications that, on the west coast of Sweden, polluted sea water, rather than polluted air, was the primary source of atmospheric mercury.

\section{Effects of the mercury added}

\section{Phytoplankton}

During POSER 1, no influence of mercury on the phytoplankton could be detected. This was probably due to inactivity of phytoplankton in the controls. Brockmann et al. (1982) hypothesize that recently upwelled water had been enclosed and that unchelated trace metals inhibited phytoplankton growth.

During POSER 2, the relative carbon assimilation. rate was inhibited after addition of $5 \mu \mathrm{g} \mathrm{Hg} \mathrm{l}^{-1}$ in the bag without nutrient addition during the whole experiment (final $\mathrm{Hg}$ concentrations ca. $1.3 \mu \mathrm{g} \mathrm{l}^{-1}$ ). In the nutrient-spiked bags phytoplankton growth was inhibited as long as mercury concentrations exceeded 2 to
$2.5 \mu \mathrm{g} \mathrm{Hg} \mathrm{l}^{-1}$. Thomas et al. (1977) and Davies and Gamble (1979), also working with enclosed plankton communities, found a transient reduction of the relative carbon assimilation rate after addition of $1 \mu \mathrm{g} \mathrm{gl}^{-1}$. Addition of 5 or $10 \mu \mathrm{g} \mathrm{Hg} \mathrm{l}^{-1}$ had stronger, but also transient inhibitory effects on the phytoplankton in these experiments. Five days after mercury addition, Thomas et al. (1977) found that phytoplankton biomass increased again in both treated enclosures, mercury concentrations being still as high as 1 and $5 \mu \mathrm{g} \mathrm{Hgl}^{-1}$, respectively. During this time the water from the enclosures was still toxic to the outside phytoplankton, indicating that the phytoplankton in the mercurytreated bags showed some adaptation. On Day 45 of the same experiment, mercury concentrations in the enclosures were no longer toxic to outside phytoplankton, although the above-mentioned mercury concentrations were still as high as 0.4 and $2.9 \mu \mathrm{g} \mathrm{Hg} \mathrm{l}^{-1}$, respectively.

In earlier experiments with Dutch coastal plankton, addition of 0.5 or $1 \mu \mathrm{g} \mathrm{Hg} \mathrm{l}^{-1}$ had no significant effects on enclosed phytoplankton. Addition of $5 \mu \mathrm{g} \mathrm{Hg} \mathrm{l}^{-1}$ inhibited the phytoplankton in all experiments, as long as mercury concentrations in the water were higher than 1.5 to $2 \mu \mathrm{g} \mathrm{Hg} \mathrm{l}^{-1}$ (Kuiper, 1977, 1980, 1981). In one experiment a single dose of $50 \mu \mathrm{g} \mathrm{Hg} \mathrm{l}^{-1}$ was added, resulting in very strong inhibition of phytoplankton for $29 \mathrm{~d}$. After this period, phytoplankton began to grow again, at mercury concentrations as high as $18 \mu \mathrm{g} \mathrm{Hg} \mathrm{l}^{-1}$.

Our experiments seem to indicate inactivation of mercury by chelation or adsorption to particles (cf. Briand et al., 1978). That relative carbon assimilation was not inhibited in the nutrient-spiked bags a few days after mercury addition, while in the bag without nutrient addition carbon assimilation was inhibited during the whole experiment, is probably due to lack of complexing substances which were not produced in such high amounts as in the nutrient-spiked bags. Another explanation, not excluding the former, may be that in the bag without nutrient addition the phytoplankton was also stressed by very low nutrient concentrations. The additional mercury stress had a stronger influence than without nutrient stress. Cloutier-Mantha and Harrison (1980) found that the threshold of mercury toxicity to Skeletonema costatum decreased by an order of magnitude when $\mathrm{NH}_{4}$-limited cultures were ammonia starved.

In earlier experiments, Kuiper $(1977,1980,1981)$ demonstrated changes in species composition after addition of mercury, probably related to reduced grazing after mercury addition. During POSER, probably less than $2 \%$ was filtered per day by the copepods (based on filtration rates given by Sonntag and Parsons, 1979). This was probably the reason why the 
species composition of phytoplankton was not changed in these experiments. Thomas et al. (1977) and Davies and Gamble (1979) also found no changes in species composition as a direct effect of mercury addition.

\section{Zooplankton}

During POSER 2, addition of $5 \mu \mathrm{g} \mathrm{Hg} \mathrm{l}^{-1}$ reduced the numbers of copepods considerably compared to controls. This was also found by Davies and Gamble (1979) and by Beers et al. (1977) after addition of 10 or $5 \mu \mathrm{g} \mathrm{Hg}$ $1^{-1}$. Beers et al. (1977) also report a delay in the development of copepod populations. In experiments in Dutch coastal waters addition of mercury always delayed the development of the copepods (Kuiper 1977, 1981). During POSER, a delay could not be shown, since copepods did not develop in the controls either at this early spring-bloom phase (Brockmann et al., 1981; Kuiper et al., 1983). The presence of nauplii indicates that the development of Calanus finmarchicus had started in a preceding period, because this species hibernates as copepodite $\mathrm{V}$ in these waters (Matthews et al., 1978).

\section{Bacteria}

During both POSER experiments numbers of bacteria were lower immediately after addition of 1 or $5 \mu \mathrm{g}$ $\mathrm{Hg} \mathrm{l}^{-1}$. These small organisms showed the quickest response. However, 6 and $10 \mathrm{~d}$ after mercury additon to the bags with and without nutrients, bacterial numbers were similar to those in the controls. As with phytoplankton, this finding indicates that nutrient addition accelerates mercury inactivation via increased production of complexing material, although development of adapted species cannot be excluded.

Davies and Gamble (1979) did not find any effects of addition of 1 of $10 \mu \mathrm{g} \mathrm{Hg} \mathrm{l}^{-1}$ on natural bacterial populations; this may also be due to their method. Azam et al. (1977), also working with natural communities, found a strong decrease of bacterial activity and numbers directly after addition of $5 \mu \mathrm{g} \mathrm{Hg} \mathrm{l}^{-1}$, followed by the development of a mercury-resistant bacterial population, which reached numbers higher than in the control.

In earlier experiments with Dutch coastal plankton, bacterial biomass was estimated by counting colonyforming units (CFU) on agar plates. A decrease after addition of $5 \mu \mathrm{g} \mathrm{Hg} \mathrm{l}^{-1}$ has never been detected, but after a period of approximately $1 \mathrm{wk}$, numbers of bacteria in polluted enclosures were always higher than in the controls (Kuiper 1980, 1981). The inhibitory effects during POSER were comparable to those obtained by
Azam et al. (1977); the stronger increase of bacteria after addition of nutrients and mercury was comparable to results obtained by Azam et al. (1977) and Kuiper $(1980,1981)$. This stronger increase is probably caused by increased substrate availability from dead phytoplankton and absence of inhibitory substances, sometimes released by exponentially growing phytoplankton (Brockmann et al., 1977). In this respect, the bacterial decrease in the non-polluted, but nutrientspiked bags, between Days 7 and 11, may be interpreted as an inhibition effect by the exponentially growing phytoplankton at this time.

\section{Comparison with other studies}

From the results available on enclosure experiments it can be concluded that mercury effects on natural plankton communities, isolated from fairly different parts of the world (Saanich Inlet, Canada; Loch Ewe, Scotland; Dutch coastal waters; Rosfjord, Norway), are very similar and that the mercury concentrations at which effects were found, are also comparable. This indicates that results obtained in Dutch coastal waters can, with some confidence, be extrapolated to other sea areas. It is interesting to compare the results of enclosure experiments with those of other toxicity studies. Several reviews concern the toxicity of mercury to aquatic life (Bryan, 1976; Stebbing, 1976; Davies, 1978; Leland et al., 1979; Taylor 1979). Laboratory experiments seldom show effects at concentrations below $1 \mu \mathrm{g} \mathrm{Hg} \mathrm{1^{-1 }}$. The lowest concentration at which effects were found in enclosure experiments was $0.5 \mu \mathrm{g} \mathrm{Hg} \mathrm{l}^{-1}$; a single dose of $0.5 \mu \mathrm{g} \mathrm{Hg} \mathrm{l}^{-1}$ changed the species composition of the periphyton (Grollé and Kuiper, 1980).

Sigmon et al. (1977) found a reduction of the diversity of an epiphyton community in artificial streams, and Saward et al. (1974) detected small effects at concentrations of $0.1 \mu \mathrm{g} \mathrm{Hg} \mathrm{l}^{-1}$. In both studies the mercury concentrations were kept constant at the desired level in a flow-through system. The organisms were constantly exposed to new doses of ionic or reactive' mercury (Davies and Gamble, 1979).

For copper and cadmium it has been shown that their toxicity is correlated with the concentration of free metal ions and not with the total metal concentration (Sunda et al., 1978; Sunda and Lewis, 1978; Engel and Fowler, 1979). Results of different bag experiments indicate that mercury is detoxified during these experiments. Addition of nutrients accelerates this process, indicating a role for organic matter as a complexing agent. These experiments, however, do not allow conclusions on the forms of mercury that are the most toxic, or on the mechanisms by which mercury is detoxified. 


\section{Effects of nutrient addition}

Addition of nutrients to small bags strongly stimulated phytoplankton growth. The rate of increase and the height of the chlorophyll maximum was comparable to that of a spring bloom in Lindaspollene, a fjord north of the Rosfjord (Lännergren and Skjoldal, 1975). As secondary effects of this enhanced primary production the amount of sediment and the rate of decrease in the amount of the added mercury were higher in the nutrient-spiked enclosures. Species composition was not affected, although percentages changed. Stimulation of primary production is often found after nutrient addition (Berland et al., 1975; Parsons et al., 1977 , 1978). Another secondary effect of the enhanced primary production was that the rate of decrease in added mercury was higher in the nutrient-spiked enclosures. This is important, since in many enclosure experiments which explicitly aim at elucidating the fate of the added pollutant, nutrients were added. If a pollutant which adsorbs to particles is added, rates of decrease will be found which are probably too high when compared with naturally occurning rates of removal (Lee et al., 1978). In these cases addition of nutrients to the enclosed plankton communities should be avoided.

By comparison of the effects of mercury in the nutrient-enriched enclosed ecosystems with the enclosures left in the original nutrient condition, it can be concluded that those plankton ecosystems would be affected most by heavy metals, which are within the regenerative mode at low nutrient concentrations. Cloutier-Mantha and Harrison (1980) came to the same conclusion on the basis of their laboratory studies with Skeletonema costatum. This applies to temperate regions during summer with succeeding anabolic and catabolic phases. But also during winter when the phytoplankton is not very active, production of dissolved organic substances is reduced so that, in particular, protection of still active bacteria will not occur.

Acknowledgements. We would like to thank Marijke van der Meer, Marian Pullens and Dr. J. H. L. Zwiers for analytical work. We gratefully acknowledge the enthusiastic help and advice of our German and Norwegian colleagues during and after POSER. Captain and crew of the RV 'Victor Hensen' are thanked for assistance during our stay in Rosfjord. The Netherlands Ministry of Foreign Affairs and the Norwegian authorities helped by providing experimental facilities in Rosfjord.

The part of these investigations carried out by Dr. Brockmann was supported by 'Deutsche Forschungsgemeinschaft' via 'Sonderforschungsbereich 94 Meeresforschung', Hamburg.

\section{IITERATURE CITED}

Azam, F., Vaccaro, R. F., Gillespie, P. A., Moussalli, E. I., Hodson, R. E. (1977). Controlled ecosystem experiment: effect of mercury on enclosed water columns. II. Marine bacterioplankton. Mar Sci. Communs 3: 313-329

Beers, J. R., Reeve, M. R., Grice, G. D. (1977). Controlled ecosystem pollution experiment: effect of mercury on enclosed water columns. V Zooplankton population dynamics and production. Mar. Sci. Communs 3: 355-394

Berland, B. R., Bonin, D. J., Maestrini, S. Y (1975). Isolement in situ d'eau de mer naturelle dans des enceintes de grand volume. CNEXO Rapp. scient. techn. 21: 1-18

Briand, F., Trucco, R., Ramamoorthy, S. (1978). Correlations between specific algae and heary metal binding in lakes. J. Fish. Res. Bd Can. 35: 1482-1485

Brockmann, U. H., Eberlein, K., Hentzschel, G., Schöne, H. K., Siebers, D., Wandschneider, K., Weber, A. (1977). Parallel plastic tank experiments with cultures of marine diatoms. Helgoländer wiss. Meeresunters. 30: 201-216

Brockmann, U. H., Dahl, E., Kuiper, J., Kattner, G. (1983). The concept of POSER (Plankton observation with simultaneous enclosures in Rosfjorden). Mar. Ecol. Prog. Ser. 14:1-8

Brockmann, U. H., Kolterman, P., Dahl, E., Dahle, A., Eberlein, K., Gaertner, A., Gassmann, G., Hammer, K., Jahnke, J., Kattner, G., Krause, M., Kuiper, J., Laake, M., Nagel, K. (1981). Water exchange in Rosfjorden during POSER. Spring 1979. Proceedings of the Symposium on Norwegian Current Systems, September 1980. Geilo, Norge, p. 93-130

Brockmann, U. H., Kattner, G., Dahl, E. (1982). Plankton spring development in a south Norwegian fjord. In: Marine mesocosms, Grice, G. D., Reeve, M. R. (ed.) Springer, New York, p. 195-204

Brosset, C., Svedung, L. (1977). Preliminary study of the possibility of a relationship between high acidity in lakes and high mercury content in their fish populations. Swed. Water Air Poll. Lab. Rep. B 378: 1-29

Bryan, G. W. (1976). Heavy metal contamination in the sea. In: Johnston, R. (ed.) Marine pollution. Academic Press, London, p. 185-302

Case, J. N. (1978). The engineering aspects of capturing a marine environment, CEPEX and others. Rapp. P.-v. Réun. Cons. int. Explor. Mer 173: 49-58

Cloutier-Mantha, L., Harrison, P. J. (1980). Effects of sublethal concentrations of mercuric chloride on ammonium-limited Skeletonema costatum. Mar. Biol. 56: 219-231

Daley, R. J., Hobbie, J E. (1975). Direct counts of aquatic bacteria by a modified epifluorescence technique. Limnol. Oceanogr. 20: 875-882

Davies, J. M., Gamble, J. C. (1979). Experiments with large enclosed ecosystems. Phil. Trans. R. Soc. Lond. B. 286: 523-544

Davies, A. G. (1978). Pollution studies with marine plankton. Part II. Heavy metals. Adv. mar. Biol. 15: 381-508

Drebes, G. (1974). Marine phytoplankton. Georg Thieme Verlag, Stuttgart

Engel, D. W., Fowler, B. A. (1979). Factors influencing cadmium accumulation and its toxicity to marine organisms Environm. Health Persp. 28: 81-88

Fisher, N. S. (1977). On the differential sensitivity of estuarine and open ocean diatoms to exotic chemical stress. Am. Nat. 111: 871-895

Fisher, N. S., Graham, L. B., Carpenter, E. J., Wurster, C. F. (1973). Geographic differences in phytoplankton sensitivity to PCB's. Nature, Lond. 241: 548-549

Fransz, H. G. (1975). The spring development of calanoid copepods populations in the Dutch coastal waters as related to primary production. In: Persoone, G., Jaspers, E. (ed.) Proceedings of 10th European Marine Biology Symposium, Vol. 2. Universa Press, Wetteren, p. 247-269 
Gray, J. S. (1974). Synergistic effects of three heavy metals on growth rates of a marine ciliate protozoan. In: Vernberg, $F$ J., Vernberg, W. B. (ed.) Pollution and physiology of marine organisms. Academic Press, New York, p, 465-485

Grice, G. D., Menzel, D. W. (1978). Controlled ecosystem pollution experiment: effect of mercury on enclosed water columns. VIII. Summary of results. Mar. Sci. Communs 4: $23-31$

Grollé, T., Kuiper, J. (1980). Development of marine periphyton under mercury stress in a controlled ecosystem experiment. Bull. environ. Contam. Toxicol. 24: 858-865

Hendey, N. I. (1964). An introductory account of the smaller algae of British coastal waters. Part V. Bacillariophyceae. Her Majesty's Stationary Office, London, p. 1-317

Hueck, H. J., Hueck van der Plas, E. H. (1976). A system of tests for potential effects of chemicals in the aqueous environment. In: Amavis, R., Smeets, J. (ed.) Principles and methods for determining ecological criteria on hydrobiocoenoses. Pergamon Press, New York, p. 467-528

Hueck, H. J., Adema, D. M. M., de Kock, W. Chr., Kuiper, J. (1978). Experiences with the validation of ecotoxicological tests. Proceedings of Research Seminar EEG u. Umweltbundesamt, Berlin 1977. UBA Ber. 10: 159-167

Hueck-Van der Plas, E. H., Hueck, H. J. (1979). The prospective assessment of environmental effects of chemicals. Drug Design 8: 311--354

Jensen, A., Rystad, B., Melsom, S. (1974). Heavy metal tolerance of marine phytoplankton. I. The tolerance of three algal species to zinc in coastal sea water. J. exp. mar. Biol. Ecol. 15: 145-157

Kuiper, J. (1977). An experimental approach in studying the influence of mercury on a North Sea coastal plankton community. Helgoländer wiss. Meeresunters. 30: 652-665

Kuiper, J. (1980). Continued investigations into pelagic microcosms subject to environmental stress by pollutants. III Combined effects of mercury and cadmium. Report MT TNO no. CL 80/85: 1-67

Kuiper, J. (1981). Fate and effects of mercury in marine plankton communities in experimental enclosures Ecotoxicol environ. Saf. 5: 106-134

Kuiper, J. (1982). Ecotoxicological experiments with marine plankton communities in plastic bags. Proceedings of the Symposium on enclosed marine experimental ecosystems, Sidney, B. C., Canada. Springer, New York, p. 181-193

Kuiper, J., Brockmann, U. H., van het Groenewoud, H., Hoornsman, G., Hammer, K. D. (1983). Influences of bag dimensions on the development of enclosed plankton communities during POSER. Mar. Ecol. Prog. Ser. 14: 9-17

Lännergren, C., Skjoldal, H. R. (1975). The spring phytoplankton bloom in Lindaspollene, a land-locked Norwegian fjord. Autrophic and heterotrophic activities in relation to nutrients. In: Persoone, G., Jaspers, E. (ed.) Proceedings of 10th European Marine Biology Symposium, Vol. 2. Universa Press, Wetteren, p. 363-391

Lee, R. F., Gardner, W S., Anderson, J. W., Blaylock, J. W. Barwell-Clarke, J. (1978). Fate of polycyclic aromatic hydrocarbons in controlled ecosystem enclosures. Environ. Sci. Technol. 12: 832-838

Leland, H. V., Luoma, S. N., Fielden, J. M. (1979). Bioaccumulation and toxicity of heary metals and related trace elements. J. Wat. Pollut. Control Fed. 51: 1592-1616

Lorenzen, C. (1967). Determination of chlorophyll and phaeopigments. Spectrophotometric equations. Limnol. Oceanogr 12: 343-346

Matthews, J. B. I., Hestad, L., Bakke, J. L. W. (1978). Ecological studies in Korsfjorden, Western Norway. The genera- tions and stocks of Calanus hyperboreus and Calanus finmarchicus in 1971-1974. Oceanologica Acta 1: 277-284

Menzel, D. W., Case, J. (1977). Concept and design: controlled ecosystem experiment. Bull. mar Sci. 27: 1- $\bar{f}$

Menzel, D. W. Steele, J. H. (1978). The application of plastic enclosures to the study of pelagic marine biota. Rapp. P.-v. Réun. Cons. int. Explor. Mer 173: 7-12

Moraitou-Apostolopoulou, M., Verriopoulos, G. (1979). Some effects of sublethal concentrations of copper on a marine copepod. Mar. Pollut. Bull. 10: 88-92

Parsons, T. R., von Brockel, K., Koeller, P., Reeve, M. R., Holm-Hansen, O. (1977). The distribution of organic carbon in a marine planktonic food web following nutrient enrichment. J. exp. mar. Biol. Ecol. 26: 235-247

Parsons, T. R., Harrison, P. J., Waters, R. (1978). An experimental simulation of changes in diatom and flagellate blooms. J. exp. mar. Biol. Ecol. 32: 285-294

Perkins, E. J. (1979). The need for sublethal studies. Phil. Trans. R. Soc. Lond. B. 286: 425-442

Saward, D., Stirling, E. A., Topping, G. (1974). Experimental studies on the effects of copper and mercury on a marine food chain. Presented at Nato Science Committee Conference on ecotoxicity of heavy metals and organo halogen compounds, Mont Gabriel, Canada. Cited by Davies and Gamble (1979)

Schelske, C. L, Stoermer, E. F. (1972). Phosphorus, silica and eutrophication of lake Michigan. In: Likens, G. E. (ed.) Nutrients and eutrophication. Spec. Symp. Am. Soc. Limnol. Oceanogr., p. 157-170

Sheldon, R. W., Parsons, T. R. (1967). A practical manual on the use of the coulter counter in marine science. Coulter electronics sales comp., Toronto

Sigmon, C. F., Kania, H. J., Beyers, R. J. (1977). Reductions in biomass and diversity resulting from exposure to mercury in artificial streams. J. Fish. Res. Bd Can. 34: 493-500

Sonntag, N. C., Parsons, T. R. (1979). Mixing an enclosed, $1300 \mathrm{~m}^{3}$ water column. Effects on the planktonic food web. J. Plankton Res. 1: 85-102

Spijk, S. J. (1975). Bepaling van sporen arseen, cadmium, chroom, koper, kwik, lood en zink in zeewater d. m. v. atomaire absorptie spectrometrie. Rep. Central Laboratory TNO, Delft, The Netherlands No. CL 75-104: 1-8

Stebbing, A. R. D. (1976). The effects of low metal levels on a clonal hydroid. J. mar. biol. Ass. U. K. 56: 977-994

Steemann Nielsen, E. (1952). The use of radioactive carbon $\left(\mathrm{C}^{14}\right)$ for measuring organic production in the sea. J. Cons. perm. int. Explor. Mer 18: 117-140

Stockner, J. G., Antia, N. J. (1976). Phytoplankton adaptation to environmental stresses from toxicants, nutrients and pollutants - a warning. J. Fish. Res. Bd Can. 33: 2089-2096

Stokes, P. M. Hutchinson, T C., Krauter, K. (1973). Heavymetal tolerance in algae isolated from contaminated lakes near Sudbury, Ontario. Can. J. Bot. 51: 2155-2168

Strickland, J. D. H., Parsons, T. R. (1968). A practical handbook of sea water analysis. Bull. Fish. Res. Bd Can. 167: $1-311$

Sunda, W. G., Lewis, J. A. M. (1978). Effect of complexation by natural organic ligands on the toxicity of copper to a unicellular alga, Monochrysis Iutheri. Limnol. Oceanogr. 23: 870-876

Sunda, W. G., Engel, D. W., Thuotte, R. M. (1978). Effect of chemical speciation on toxicity of cadmium to grass shrimp, Palaemonetes pugio: importance of free cadmium ion. Environ. Sci. Technol. 12: 409-413

Takahashi, M., Wallace, G. T., Whitney, F. A., Menzel, D. W (1977). Controlled ecosystem pollution experiment: effect 
of mercury on enclosed water columns. I. Manipulation of experimental enclosures. Mar. Sci. Communs 3: 291-312

Taylor, D. (1979). A review of the lethal and sublethal effects of mercury on aquatic life. Residue Rev. 72: 33-70

Thomas, W. H., Seibert, D. L. R., Takahashi, M. (1977). Controlled ecosystem pollution experiment: effect of mercury on enclosed water columns III Phytoplankton population dynamics and production. Mar. Sci. Communs 3: 331-354

Tjioe, P. S., de Goeij, J. J. M., Houtman, J. P. W. (1973). Automated chemical separations in routine activation analysis. J. radioanalyt. Chem. 16: 153-164

Topping, G., Davies, I. M., Pirie, J. M. (1982). Processes affecting the movement and speciation of mercury in the marine environment. Proceedings of the Symposium on marine enclosed experimental ecosystems, Sidney, B. C., Canada. Springer, New York, p. 167-179

Wollast, R., Billen, G., Mackenzie, F. T. (1975). Behaviour of mercury in natural systems and its global cycle. In: McIntyre, Mills, C. F. (ed.) Ecological toxicology research. Plenum Press, New York, p. 145-166

Zeitzschel, B. (1978). Controlled environment experiments in pollution studies. Proceedings of Oceanology Int. 78, Tech. Sess. B. (Biol. Mar. Tech), p. 21-32

Zimmerman, J. T. F., Rommets, J. W. (1974). Natural fluorescence as a tracer in the Dutch Wadden Sea and the adjacent North Sea. Neth. J. Sea Res. 8: 117-125

This paper was submitted to the editor; it was accepted for printing on July 31,1983 